FACTA UNIVERSITATIS

Series: Physical Education and Sport, Vol. 18, No 1, 2020, pp. 145 - 157

https://doi.org/10.22190/FUPES191219001S

Research article

\title{
THE EFFECTS OF SKILL-BASED EXERCISES AND A SMALL-SIDED GAMES PROGRAM ON THE BODY COMPOSITION OF ADOLESCENTS
}

\author{
UDC 796.012.01
}

\section{Darko Stojanović ${ }^{1}$, Nataša Branković ${ }^{2}$ Tijana Stojanović ${ }^{2}$, Zoran Momčilović}

${ }^{1}$ Faculty of Sport, University Union-Nikola Tesla, Belgrade, Serbia ${ }^{2}$ Faculty of Sport and Physical Education, University of Niš, Niš, Serbia

${ }^{3}$ Teacher Training Faculty, University of Niš, Vranje, Serbia

\begin{abstract}
The purpose of this experimental study was to determine the effects of a skillbased exercise program on the body composition of adolescents. The study was conducted on 90 participants, (age, 13 \pm 6 years), divided by gender then randomly assigned into two sub-samples: the experimental [SS1, $N=39$ (EG1, 19 girls and EG2, 20 boys)] and the control group [SS2, N=51 (CG1, 24 girls and CG2, 27 boys)]. Body composition parameters were assessed by a caliper (skinfold thickness) and bioelectrical impedance analyzer Omron BF511 (percentage of body fat tissue and muscle tissue). After conducting the 16-week program of skill-based exercises and small-sided games (SSG) related to volleyball, certain body composition parameters statistically significantly increased in the experimental groups (except body fat percent in girls, and body fat mass in both genders). In the experimental period, the SS2 increased in body fat tissue (both genders) and in muscle tissue (girls), while a decrease in muscle tissue was recorded among the boys. The results of this study showed no significant differences in the effects of the two programs on body composition at the multivariate level for both genders. Furthermore, at the univariate level it was noted that the students following the experimental program (SS1) had better results compared to the SS2 of students in terms of the decrease of body fat tissue, as well as the increase of muscle tissue for both genders. The obtained results indicate that the program of skill-based exercises and SSG related to volleyball is suitable for adequate intensification of PE classes and improvement of body composition parameters of elementary school students.
\end{abstract}

Key words: Skill-Based Exercise, Small-Sided Games, Body Composition, Physical Education, Adolescents.

Received December 19, 2019/ Accepted March 12, 2020

Corresponding author: Darko Stojanović

Faculty of Sport, University Union - Nikola Tesla, Narodnih heroja 3/I, 11070 Novi Beograd, Serbia

Phone: + 3811140440 50•E-mail: darko89_nish@hotmail.com

(C) 2020 by University of Niš, Serbia | Creative Commons License: CC BY-NC-ND 


\section{INTRODUCTION}

Daily physical activity (PA) levels have decreased and the prevalence of obesity increased in adolescents in the last 20 years. This global phenomenon is alarming for public health, as obesity has reached epidemic proportions (WHO, 2016). The low level of PA is defined as one of the many causal factors for obesity development (Hills, Andersen, \& Byrne, 2011; Ekelund et al., 2012). Excess body composition parameters such as body fat in adolescents are associated with the risk of cardiovascular diseases, affecting quality of life and reducing the average life expectancy (Pate, Heath, Dowda, \& Trost, 1996; Rey-López, Vicente-Rodriguez, Biosca, \& Moreno, 2008; Nathan \& Moran, 2008; Han, Lawlor, \& Kimm, 2010; Regaieg et al., 2013; Stojanović \& Branković, 2018). The main remedy for adolescent's obesity is an increase in the level of PA during leisure time but also in schools as a part of the physical education (PE) curriculum.

The PE is very important part of education because it can contribute to growth, optimal motor skills development, changes in body composition and psycho-social characteristics of individual by proposing appropriate physical activities (Fairclough \& Stratton, 2004; Hardman, 2007).

Early studies investigating the quality of the PE curriculum showed that the current curriculum is ineffective in the aspect of providing the appropriate frequency, duration and intensity which could provide stimuli for anthropometric and physical fitness characteristics improvement among adolescents (Sallis et al., 1997; Stojanović, 1998; Branković, 2001; Milenković, 2002; Dragić, 2003; Koutedakis \& Bouziotas, 2003; Jurg et al., 2006; Kirk, 2006; Stamatović \& Šekeljić, 2006; Trost, 2006). Based on the above stated facts, PE curriculum goals and objectives cannot be accomplished at full scale, hence intensification of PE classes becomes urgent to investigate (Stojanović, Momčilović, Stojanović, \& Stojanović 2019).

Determination of PE class modality and workload volume is very complex process and it hasn't been investigated to a satisfactory extent. It represents an inexhaustible source for further study in order to find more precise solutions (Pate et al., 2006).

In a review paper by Harvey \& Jarrett (2014), plenty of research has tried to find better solutions for students' engagement in PE classes through the implementation of sport programs, modified games, small-sided and conditioned games using models with different approaches (e.g. game-centered approaches - GCAs) than the traditional one.

Skill-based exercises (SBE) share similarity with real competitive volleyball situations in aspect of structure and intensity of the player movement (Grgantov, 2003). This similarity provides training exercises to be closer to competitive demands and also contribute to engage preferable stimuli for the muscles that are important in specific movements during competition (Trajković, 2015). SBE provide the simulation of volleyball match movement patterns to students in such an environment they have to exercise actively under pressure and high intensity (Gabbet, 2002). The purpose of SBE is faster technique adoption, and manipulation of game or specific exercise to reach higher or to maintain appropriate workload intensity.

The concept of small-sided games (SSG) such as "mini-volleyball" is based on simplified rules of the game and reduced size of playing court in order to make game much more intense. Also by reducing the number of players on court, students are making more frequent contact with the ball ensuing easier and faster adoption of volleyball techniques (Marelić, Janković, Rešetar, \& Marelić, 2000). As such, mini-volleyball makes the game 
much more intense and interesting, which fully meets the needs of students for PA, motor and social development. In mini-volleyball, more precisely in the 3 vs. 3 game, in one set more average contacts with the ball and fewer errors in the game are achieved. The students achieve 27.7 ball contacts more compared to the traditional 6 vs. 6 game (Rešetar, Đurković, Marelić, \& Borovina, 2008).

The aim of this study is to determine the effects of 16-week program of skill-based exercises and SSG related to volleyball on changes in body composition parameters of the experimental groups. The additional aim of this study is to determine the effects of a regular PE curriculum on the body composition parameters of the control groups during the same period.

\section{METHODS}

\section{The sample of participants}

The sample of participants were comprised of 90 seventh grade students (age: $13 \pm 6$ months) of the Elementary School "Duško Radović" in Niš. The study sample involved only students who agreed voluntarily to participate in the study followed by testing program and physical exercise. Prior study, parental consents were obtained for every participant. The study protects the children's privacy by allowing for anonymity and was designed in compliance with the recommendations for clinical research of the World Medical Association Declaration of Helsinki (2013). This study was also reviewed and approved by the Ethics Committee of the Faculty of Sport and Physical Education, University of Niš. The additional inclusion criteria was that the students must be clinically healthy during testing protocol and should not be exempted from PE classes. For the final processing, only the results of the participants who participated in both measurements (initial and final) and had no more than two absences per month were included. The participants were firstly divided by gender than randomly assigned into the experimental and control subsamples:

1. The experimental subsample (SS1), consisted of the group of 19 girls (EG1, BH: $160.75 \mathrm{~cm}$; BM: $55.32 \mathrm{~kg}$ ) and of the group of 20 boys (EG2, BH: $164.28 \mathrm{~cm}$; BM: $56.44 \mathrm{~kg}$ ) and

2. The control subsample (SS2), consisted of the group of 24 girls (CG1, BH: $159.10 \mathrm{~cm}$; BM: $48.04 \mathrm{~kg}$ ) and of the group of 27 boys (CG2, BH: $166.30 \mathrm{~cm}$; BM: $56.76 \mathrm{~kg})$.

\section{Anthropometric measurements and body composition}

Following anthropometric assessment protocols by Norton et al. (2001) body height (BH) was measured via Martin anthropometer GPM 101 (GPM GmbH Switzerland) and values were recorded in millimeters $(\mathrm{mm})$. Body mass $(\mathrm{BM})$ was measured with a digital body mass scale Omron BF511 (Omron Healthcare Co, Kyoto, Japan) with an accuracy of $0.1 \mathrm{~kg}$. Skinfold thickness was measured using GPM 6100 (GPM GmbH Switzerland), at the triceps, subscapular and suprailiac sites, with an accuracy of $0.2 \mathrm{~mm}$ according to the methodology recommended by the International Biological Program (Weiner \& Lourie, 1969). A GPM caliper provides a constant pressure of $10 \mathrm{~g} / \mathrm{mm}^{2}$. The measurement 
results were evaluated 2 seconds after the grip was caught on the skin. All three sites of skinfold thickness were summed up to provide the sum of skinfolds (SUM3). Body composition components BF\% and MM\% were assessed using the BIA digital scale Omron BF511. The participants were requested to avoid the following procedures before body composition measurement as described by Rech, Cordeiro, Petroski, \& Vasconcelos (2008): not to perform any physical exercises during 12 hours before testing, not to eat or drink anything during the four hours before the evaluation, to urinate at least 30 minutes before the evaluation, not to take any diuretics during the seven days prior to the test.

\section{Procedures}

The SS2 students attended total of 3 classes per week. Two classes of regular PE and one elective PE class (volleyball), following curriculum of the Serbian Ministry of Education (Official Gazette of the Republic of Serbia, 2006).

The SS1 students also attended total of 3 classes per week. Two classes of regular PE classes following curriculum of the Serbian Ministry of Education and an one elective PE class (volleyball) following the experimental program of SBE and SSG.

The SS1 students followed up the 16-week experimental program of SBE and SSG during elective PE class. Class was designed with classic four-part class structure, which included 3-5 minutes intensity activities such as specific volleyball warm-up, musclestrengthening and mobility increase exercises in the function of physically introducing the students to the upcoming activities. The main part of the class included skill-based exercises with high intensity (70\%-90\% HRmax), and SSG (mini-volleyball) 2 vs. 2, 3 vs. 3 and 4 vs. 4 .

\section{Statistical analyses}

For the assumption of normality, the Kolmogorov-Smirnov test was applied to analyze the result distribution for the initial and final measurements for both groups. Univariate analysis of variance for repeated measures (ANOVA) was applied to determine the differences between the initial and final measurements of the participants. The effect size was calculated using the partial eta squared $\left(\eta_{p}^{2}\right)$, according to Keppel (1991). Effect size (ES) values are classified according to Ferguson (2009) as: no effects (NE) if $0 \leq \eta_{\mathrm{p}}^{2}<0.05$; small effect (SE) if $0.05 \leq \eta_{p}^{2}<0.26$; moderate effect (ME) if $0.26 \leq \eta_{p}^{2}<0.64$; and a large effect (LE) if $\eta_{p}^{2} \geq 0.64$. For determination of the effects of the experimental program multivariate and univariate analysis of covariance (MANCOVA/ANCOVA) were used. Level of statistical significance was set at $\mathrm{p} \leq 0.05$. Statistical procedures and analyses were conducted using the statistical package STATISTICA 10.0 for Windows (StatSoft, Inc., Tulsa).

\section{RESUlts}

The results of the Kolmogorov-Smirnov test for the body composition parameters at the initial and final measurement of both genders in the SS1 and SS2, confirmed the assumption of normal distribution for all included variables, thus the parametric statistical analyses can be performed. 
After confirmed assumption of normality and observation of descriptive statistics results across groups, further analyses were made possible by the parametric statistics. To determine the differences between the initial and final measurements, repeated measures ANOVA was carried out, as well as the MANCOVA/ANCOVA to determine the effects of the experimental program.

The results of the univariate analysis of the differences between the initial and final measurements of the EG1 of the girls (Table 1) showed that three body composition parameters have statistically significantly better results at the final measurement compared to the initial one. The difference between the measurements with a large effect was manifested in the variable $\mathrm{MM}(\mathrm{F}=31.66 ; \mathrm{ES}=0.64)$, while the differences with moderate effects are observed in SUM3 (F=22.30; ES=0.55) and MM\% $(\mathrm{F}=21.70 ; \mathrm{ES}=0.55)$.

Table 1 Differences between the initial and final measurements for the experimental group of the girls (EG1)

\begin{tabular}{|c|c|c|c|c|c|c|}
\hline \multirow[t]{2}{*}{ Variables } & \multicolumn{2}{|c|}{ Mean } & \multicolumn{2}{|c|}{ Std. Dev. } & \multirow[t]{2}{*}{$\mathrm{F}(1 ; 18)$} & \multirow[t]{2}{*}{$\mathrm{ES}$} \\
\hline & In & Fin & In & Fin & & \\
\hline SUM3 ${ }^{(\mathrm{mm})}$ & 40.91 & $38.13^{*}$ & 13.79 & 12.23 & 22.30 & $0.55^{\mathrm{ME}}$ \\
\hline $\mathrm{BF} \%{ }^{(\%)}$ & 25.56 & 25.32 & 8.19 & 8.27 & 3.83 & $0.18^{\mathrm{SE}}$ \\
\hline $\mathrm{BF}^{(\mathrm{kg})}$ & 14.94 & 14.88 & 8.05 & 7.83 & 0.37 & $0.02^{\mathrm{NE}}$ \\
\hline MM\% ${ }^{(\%)}$ & 33.32 & $33.74^{*}$ & 2.61 & 2.72 & 21.70 & $0.55^{\mathrm{ME}}$ \\
\hline $\mathrm{MM}^{(\mathrm{kg})}$ & 18.20 & $18.59^{*}$ & 2.95 & 2.81 & 31.66 & $0.64^{\mathrm{LE}}$ \\
\hline
\end{tabular}

The results of the univariate analysis of the differences between the initial and final measurements of the CG1 of girls (Table 2) indicate that there were statistically significant differences in $\mathrm{BF}(\mathrm{F}=13.33 ; \mathrm{ES}=0.37)$ and $\mathrm{BF} \%(\mathrm{~F}=6.80 ; \mathrm{ES}=\mathrm{SE})$ with better results at the initial measurement (less body fat), and significantly better results in $\mathrm{MM}$ $(\mathrm{F}=30.15 ; \mathrm{ES}=0.57)$ at the final measurement.

Table 2 Differences between the initial and final measurements for the control group of the girls (CG1)

\begin{tabular}{|c|c|c|c|c|c|c|}
\hline \multirow[t]{2}{*}{ Variables } & \multicolumn{2}{|c|}{ Mean } & \multicolumn{2}{|c|}{ Std. Dev. } & \multirow[t]{2}{*}{$\mathrm{F}(1 ; 23)$} & \multirow[t]{2}{*}{ ES } \\
\hline & In & Fin & In & Fin & & \\
\hline SUM3 $^{(\mathrm{mm})}$ & 35.70 & 37.31 & 7.90 & 8.43 & 2.63 & $0.10^{\mathrm{SE}}$ \\
\hline $\mathrm{BF} \%{ }^{(\%)}$ & $20.69^{*}$ & 21.46 & 6.12 & 5.89 & 6.80 & $0.23^{\mathrm{SE}}$ \\
\hline $\mathrm{BF}^{(\mathrm{kg})}$ & $10.27^{*}$ & 10.92 & 4.13 & 4.15 & 13.33 & $0.37^{\mathrm{ME}}$ \\
\hline MM\% ${ }^{(\%)}$ & 34.85 & 34.67 & 1.79 & 1.79 & 3.13 & $0.12^{\mathrm{SE}}$ \\
\hline $\mathrm{MM}^{(\mathrm{kg})}$ & 16.67 & $17.07 *$ & 2.17 & 2.19 & 30.15 & $0.57^{\mathrm{ME}}$ \\
\hline
\end{tabular}

In the results of the univariate analysis of the differences between the initial and final measurements of the EG2 of boys (Table 3), it is observed that four of the five applied body composition variables have significantly better results at the final measurement. A significant difference between the measurements with a large effect was manifested in SUM3 ( $F=36.41 ; E S=0.66)$, with a moderate effect among two variables $-\mathrm{MM}(\mathrm{F}=15.37$; 
$\mathrm{ES}=0.45)$ and $\mathrm{BF} \%(\mathrm{~F}=12.67 ; \mathrm{ES}=0.40)$, and a difference with a small effect was observed for $\mathrm{MM} \%(\mathrm{~F}=6.26 ; \mathrm{ES}=0.25)$.

Table 3 Differences between the initial and final measurements for the experimental group of the boys (EG2)

\begin{tabular}{lccrrrr}
\hline Variables & \multicolumn{2}{c}{ Mean } & \multicolumn{2}{c}{ Std. Dev. } & F $(1 ; 19)$ & ES \\
\cline { 2 - 5 } & \multicolumn{1}{c}{ In } & Fin & \multicolumn{1}{c}{ In } & \multicolumn{1}{c}{ Fin } & & \\
\hline SUM3 $^{(\mathrm{mm})}$ & 40.34 & $34.96^{*}$ & 13.74 & 12.77 & 36.41 & $0.66^{\mathrm{LE}}$ \\
BF\% $^{(\%)}$ & 20.77 & $19.95^{*}$ & 7.33 & 7.23 & 12.67 & $0.40^{\mathrm{ME}}$ \\
BF $^{(\mathrm{kg})}$ & 12.03 & 12.08 & 5.37 & 5.68 & 0.14 & $0.01^{\mathrm{NE}}$ \\
MM\% $^{(\%)}$ & 37.27 & $37.81^{*}$ & 3.00 & 2.79 & 6.26 & $0.25^{\mathrm{SE}}$ \\
MM $^{(\mathrm{kg})}$ & 20.92 & $22.08^{*}$ & 3.41 & 3.97 & 15.37 & $0.45^{\mathrm{ME}}$ \\
\hline
\end{tabular}

Legend: Mean - arithmetic means; Std.Dev. - standard deviation; ${ }^{*}$ - significant at the $\mathrm{p} \leq 0.05$ level; In - initial measurement; Fin - final measurement; F - F test value; ES - Effect Size

The differences between the initial and final measurement for the CG2 of boys (Table 4), showed the presence of significant differences in three body composition parameters with a better results at the initial measurement - $\mathrm{BF}(\mathrm{F}=9.01 ; \mathrm{ES}=0.26), \mathrm{MM} \%(\mathrm{~F}=7.93$; $\mathrm{ES}=0.23)$, and $\mathrm{BF} \%(\mathrm{~F}=4.62 ; \mathrm{ES}=0.26)$.

Table 4 Differences between the initial and final measurements for the control group of the boys $(\mathrm{CG} 2)$

\begin{tabular}{|c|c|c|c|c|c|c|}
\hline \multirow[t]{2}{*}{ Variables } & \multicolumn{2}{|c|}{ Mean } & \multicolumn{2}{|c|}{ Std. Dev. } & \multirow[t]{2}{*}{$\mathrm{F}(1 ; 26)$} & \multirow[t]{2}{*}{$\mathrm{ES}$} \\
\hline & In & Fin & In & Fin & & \\
\hline SUM3 $^{(\mathrm{mm})}$ & 33.02 & 33.93 & 9.17 & 11.08 & 0.76 & $0.03^{\mathrm{NE}}$ \\
\hline $\mathrm{BF} \%{ }^{(\%)}$ & $15.77^{*}$ & 16.33 & 6.26 & 5.67 & 4.62 & $0.15^{\mathrm{SE}}$ \\
\hline $\mathrm{BF}^{(\mathrm{kg})}$ & $8.97^{*}$ & 9.52 & 4.09 & 4.15 & 9.01 & $0.26^{\mathrm{ME}}$ \\
\hline MM\% ${ }^{(\%)}$ & $39.41^{*}$ & 39.05 & 2.54 & 2.52 & 7.93 & $0.23^{\mathrm{SE}}$ \\
\hline $\mathrm{MM}^{(\mathrm{kg})}$ & 22.41 & 22.55 & 4.65 & 4.65 & 1.26 & $0.05^{\mathrm{SE}}$ \\
\hline
\end{tabular}

A multivariate analysis of covariance of the applied body composition variables between the EG1 and CG1 of girls at the final measurement with controlling for initial measurement (covariate) is shown in Table 5. After the analysis, it can be stated that a statistically significant difference among the groups at the required level of $Q<.05$ was found $(\mathrm{Q}=0.002)$. It is evident that the experimental program of SBE and SSG at the multivariate level had a greater effect on body composition than the regular school PE program.

Further analyses at the univariate level, (Table 5), reveal statistically significant differences in muscle mass percent (MM\%: $\mathrm{F}=11.98, \mathrm{p}=0.001$ ), sum of three skinfolds (SUM3: $\mathrm{F}=9.21, \mathrm{p}=0.004)$, body fat mass $(\mathrm{BF}: \mathrm{F}=5.76, \mathrm{p}=0.022)$ as well as in body fat percent $(\mathrm{BF} \%$ : $\mathrm{F}=5.25, \mathrm{p}=0.028)$, where the $\mathrm{EG} 1$ of girls achieved better results. Muscle mass - MM, did not show a statistically significant difference between the groups, but it is evident that the EG of girls achieved greater progress than the CG1 of girls at the numerical level. 
Table 5 The effects of the EG1 and CG1 programs on body composition among girls (MANCOVA/ANCOVA)

\begin{tabular}{|c|c|c|c|c|}
\hline Variables & $\begin{array}{c}\text { Adj. Mean } \\
\text { EG }\end{array}$ & $\begin{array}{c}\text { Adj. Mean } \\
\text { CG }\end{array}$ & $\mathrm{F}^{2}(1 ; 36)$ & $\mathrm{p}$ \\
\hline $\mathrm{SUM}^{(\mathrm{mm})}$ & $35.67^{*}$ & 39.77 & 9.21 & $0.004^{*}$ \\
\hline $\mathrm{BF} \%(\%)$ & $22.93^{*}$ & 23.85 & 5.25 & $0.028^{*}$ \\
\hline $\mathrm{BF}^{(\mathrm{kg})}$ & $12.60^{*}$ & 13.19 & 5.76 & $0.022^{*}$ \\
\hline MM\% ${ }^{(\%)}$ & $34.49^{*}$ & 33.92 & 11.98 & $0.001^{*}$ \\
\hline $\mathrm{MM}^{(\mathrm{kg})}$ & 17.84 & 17.81 & 0.12 & 0.735 \\
\hline Wilks Lambda & $\mathrm{F}^{1}$ & Effect - df & Error - df & $\mathrm{Q}$ \\
\hline 0.567 & 4.89 & 5 & 32 & $0.002 *$ \\
\hline
\end{tabular}

Legend: Adjusted means - adjusted values of the arithmetic means; $\mathrm{F}^{2}$ - value of the F-test coefficient;

* - statistical significance; Wilks lambda - value of the Wilk's test coefficient for group centroid equality; $\mathrm{F}^{1}$ - value of the F-test coefficient for the significance of Wilk' lambda; Effect df; Error df - degrees of freedom; Q - centroid difference significance.

Table 6 shows that there is statistically significant difference between the groups of boys at the multivariate level. The experimental program of SBE and SSG had greater effects on the body composition parameters than the school PE program among boys at the multivariate level $(\mathrm{Q}=0.005)$, while at the univariate level, statistically significant differences were observed in the sum of three skinfolds (SUM3: $\mathrm{F}=13.92, \mathrm{p}=0.001$ ), muscle mass percent (MM\%: $\mathrm{F}=10.27, \mathrm{p}=0.003$ ), muscle mass (MM: $\mathrm{F}=7.19, \mathrm{p}=0.011$ ) and body fat percent $(\mathrm{BF} \%: \mathrm{F}=6.44, \mathrm{p}=0.015)$, where the boys of the $\mathrm{EG} 2$ achieved better results than those of the CG2. It is evident that the boys from the EG2 made greater progress than the boys of the CG2, while no statistical significance was observed in body fat mass - BF.

Table 6 The effects of the EG and CG programs on body composition among boys (MANCOVA/ANCOVA)

\begin{tabular}{|c|c|c|c|c|}
\hline Variables & $\begin{array}{c}\text { Adj. Mean } \\
\text { EG }\end{array}$ & $\begin{array}{c}\text { Adj. Mean } \\
\text { CG }\end{array}$ & $\mathrm{F}^{2}(1 ; 40)$ & $\mathrm{p}$ \\
\hline SUM3 ${ }^{(\mathrm{mm})}$ & $31.70^{*}$ & 37.19 & 13.92 & $0.001^{*}$ \\
\hline $\mathrm{BF} \%(\%)$ & $17.68^{*}$ & 18.61 & 6.44 & $0.015^{*}$ \\
\hline $\mathrm{BF}^{(\mathrm{kg})}$ & 10.61 & 10.99 & 2.16 & 0.149 \\
\hline MM\% ${ }^{(\%)}$ & $38.77^{*}$ & 38.08 & 10.27 & $0.003^{*}$ \\
\hline $\mathrm{MM}^{(\mathrm{kg})}$ & $22.66^{*}$ & 21.97 & 7.19 & $0.011^{*}$ \\
\hline Wilks Lambda & $\mathrm{F}^{1}$ & Effect - df & Error - df & Q \\
\hline 0.639 & 4.07 & 5 & 36 & $0.005^{*}$ \\
\hline
\end{tabular}

Legend: Adjusted means - adjusted values of the arithmetic means; $\mathrm{F}^{2}$ - value of the F-test coefficient;

* - statistical significance; Wilks lambda - value of the Wilk's test coefficient for group centroid equality; $\mathrm{F}^{1}$ - value of the F-test coefficient for the significance of Wilk' lambda; Effect df; Error df - degrees of freedom; Q - centroid difference significance. 


\section{DISCUSSION}

The aim of this study was to determine the effects of the SBE and SSG program on the body composition parameters of groups of adolescents. The additional aim of this study was to determine the effects of the regular PE curriculum on the body composition parameters of the CG.

The results of the present study showed that $13 \pm 6$ year-old elementary school students who participated in the SBE and SSG program (SS1) over a 16-week period showed a decrease of skinfold thickness (both genders) and body fat tissue (boys), and an increase of muscle tissue (both genders). Furthermore, the results showed that the students who participate in the regular PE curriculum (SS2) over the same period, have increased body fat tissue (both genders) and muscle tissue (girls), while a decrease in muscle tissue was recorded among the boys.

After controling for the results from initial measurement, an analysis of covariance showed significant differences between the effects of the two programs, with more favourable changes in body composition parameters such as skinfold thickness, body fat tissue, and muscle tissue in the SS1 than in the SS2, similar for both genders. The most favourable changes with large effects occurred in the SUM3 variable which represents the sum of three truncal skinfold thickness values (triceps, subscapular and suprailiac). While body fat percent is a good indicator of the total amount of adipose tissue in the body, anthropometric measures of truncal skinfolds are good indicators of the distribution of subcutaneous adipose tissue in the central region which is known to be related with health risks (Deurenberg, Pieters, \& Hautvast, 1990; Snijder, Van Dam, Visser, \& Seidell, 2005; Pereira et al., 2015).

This outcome of the SS2 in both genders was expected, considering that many previous studies characterize the regular PE curriculum as ineffective in terms of appropriate frequency, duration and intensity (Milenković, 2002; Koutedakis \& Bouziotas, 2003; Jurg et al., 2006; Kirk, 2006; Trost, 2006). In the research by Zegnal-Koretic (2017), the author stated that there is a prevalence of overweight children, who are in the pre-obesity and obesity phase, with a transition to higher grades. The author states that in the fifth grade about $13 \%$ of overweight children ( $8 \%$ pre-obese; $4.9 \%$ obese) were recorded, while in the 8 th grade $20 \%$ of overweight adolescents (14\% pre-obese; $5.8 \%$ obese) were registered. The above facts indicate that the current PE curriculum fails to meet the needs of students, especially in a period of rapid growth and development, where engagement in PA is very important for proper musculoskeletal development and body fat reduction.

The results obtained on the effectiveness of the implemented the SBE and SSG program are in accordance with the previous studies evaluating specially designed sport-based programs as a part of the curriculum, or as extracurricular activities (sports class, sport specific training, etc.). Volleyball drills and skills combined with physical conditioning increase the intensity of volleyball-specific training and as such can contribute to increased muscle mass percent for a short period of 4 weeks among young female volleyball players (Stojanović, Bešić, Stojanović, Lilić, \& Zadražnik, 2018). In a study by Ljubojević, Višnjić, \& Ilić (2012), content related to basketball showed positive effects on the morphological characteristics in boys, to a smaller extent, and in girls, to a greater extent. Results from studies that evaluated programs in the form of SSG related to soccer, with intensity above $70 \%$ HRmax, showed that soccer games with reduced numbers of players ( 3 vs. 3 ) compared with a higher number of players (5 vs. 5) achieved a greater amount of engagement (frequent 
contact with the ball) and higher heart rates (Owen, Twist, \& Ford, 2004). Also, SSG related to soccer showed a body fat reduction in boys, after a period of 11-12 weeks (Carrasco, Reigal, Ulloa, Chirosa, \& Chirosa, 2015; Milanović, Pantelić, Kostić, Trajković, \& Sporiš, 2015), but after a shorter period of 8 weeks showed no significant effects on body composition parameters (Hammami et al., 2018). Different exercise programs, but still with an intensity above $70 \%$ HRmax, also achieved a reduction in skinfold thickness (Lazaar et al., 2007; Farias et al., 2009), body fat tissue (Regaieg et al., 2013) and an increase in muscle tissue (Lazaar et al., 2007; Farias et al., 2009; Regaieg et al., 2013) among adolescents.

Recorded progress in the SS1 among girls and boys in terms of body composition parameters can be attributed to the applied experimental treatment, but it should be taken into consideration that the students were in the period of an adolescent growth spurt, where the occurrence of accelerated growth and development is present, especially in anthropometric characteristics such as body height and body mass, as well as changes in certain parameters of body composition, depending on biological maturity and gender. One of the indicators of biological maturity is Peak Height Velocity (PHV) and represents the maximum growth rate during accelerated development in adolescence (Mirwald, BaxterJones, Bailey, \& Beunen, 2002). The maximum growth rate in adolescence begins between the ages of 12 and 14 for both sexes (Viru et al., 1999; Mirwald et al., 2002).

Girls and boys in young adolescence have approximately the same values of the body mass index (BMI) until the seventh grade, when a dramatic decrease occurs among boys, due to accelerated body height gain Zegnal-Koretić (2017). BMI values in this study were used only to specify the characteristics of the sample, and were not monitored during an experimental period regarding serious limitations of BMI as an index of adiposity in children (Garn, Leonard, \& Hawthorne, 1986).

Comparing the results of cross-sectional studies, Malina (2004) stated that muscle tissue growth of girls and boys is nearly linear around puberty, with slightly higher values among boys, where increment in muscle tissue is associated with the growth hormone, and from puberty with testosterone. Hormonal changes during puberty lead to an increase in adipose tissue in girls and lean body mass in both sexes (Siervogel et al., 2003). Adipose tissue increases to a much greater extent in girls because body fat represents an essential energy deposit, which is required for the normal functioning of female gonads (Phillips, Bandini, Compton, Naumova, \& Must, 2003). After the age of 11, the amount of adipose tissue in boys decreases, while in girls it increases (Viru et al., 1999; Schwandt, von Eckardstein, \& Haas, 2012). In boys, the level of androgens is higher than the level of estrogen leading to masculinization, and in girls, the level of estrogen is higher than the level of androgens, so feminization occurs (Pinel, 2010).

Based on the above mentioned changes in parameters of body composition during adolescence, it can be concluded that students were at specific stage of development followed bv facts that hormonal changes, along with accelerated growth, development, and puberty occurs in middle school age (11-15 years).

The experimental program of the SBE and SSG caused changes in the parameters of body composition among the girls with respect to the reduction of adipose tissue during maturation when, from a biological point of view, the accumulation of body fat is an essential deposit of energy required for full sexual maturation. The experimental program also contributed to the increase in muscle tissue in girls and boys, as well as the reduction of adipose tissue in boys, which is consistent with the growth hormone most prevalent 
during adolescence, especially in boys. For these reasons, some biological factors that affect changes in body composition during adolescence are very important to monitor, in order to properly plan and program PE classes to meet the needs of students, as well as their motor and biopsychosocial development.

\section{CONCLUSION}

From the obtained results from this research, it can be concluded that the experimental program of skill-based exercises and small-sided games, designed with increased intensity of the elective PE class (volleyball), contributed to significant changes in the body composition parameters, more precisely, a reduction in skinfold thickness and total body fat, and muscle mass increment of elementary school students. Obtained information clearly indicates that experimental program have the greater effectiveness and superiority comparing the current PE curriculum effects.

\section{REFERENCES}

Branković, N. (2001). Razvojne karakteristike motoričkih sposobnosti učenica na kraju šestomesečnog izvođenja nastave fizičkog vaspitanja (Developmental characteristics of students' motor skills at the end of six months of physical education classes). In S. Vučković (Ed.). Proceedings of the Scientific Congres "FIS Communications in Physical Education, Sport and Recreation" (pp. 205-207). Niš: Faculty of Physical Culture, University of Niš. In Serbian

Carrasco, H.B., Reigal, R.G., Ulloa, D.D., Chirosa, I.R., \& Chirosa, L.R. (2015). Effects of small-sided exercises on body composition and maximal oxygen uptake in adolescents. Revista medica de Chile, 143(6), 744-750.

Deurenberg, P., Pieters, J.J., \& Hautvast, J.G. (1990). The assessment of the body fat percentage by skinfold thickness measurements in childhood and young adolescence. British Journal of Nutrition, 63(2), 293-303.

Dragić, B. (2003). Efekti alternativnog nastavnog plana i programa fizičkog vaspitanja na morfološke karakteristike, motoričke sposobnosti i socijalne karakteristike učenika VI razreda osnovne škole (Effects of alternative physical education curriculum on morphological characteristics, motor skills and social characteristics of elementary school students). Unpublished doctoral dissertation, Niš: Faculty of Physical Culture, University of Niš. In Serbian

Ekelund, U., Luan, J.A., Sherar, L.B., Esliger, D.W., Griew, P., Cooper, A., et al. (2012). Moderate to vigorous physical activity and sedentary time and cardiometabolic risk factors in children and adolescents. Jama, 307(7), 704-712.

Fairclough, S., \& Stratton, G. (2004). 'Physical education makes you fit and healthy'. Physical education's contribution to young people's physical activity levels. Health Education Research, 20(1), 14-23.

Farias, E.S., Paula, F., Carvalho, W.R., Gonçalves, E.M., Baldin, A.D., \& Guerra-Júnior, G. (2009). Influence of programmed physical activity on body composition among adolescent students. Jornal de Pediatria, 85(1), 28-34.

Ferguson, C.J. (2009). An effect size primer: a guide for clinicians and researchers. Professional Psychology: Research and Practice, 40(5), 532-538.

Gabbett, T.J. (2002). Training injuries in rugby league: an evaluation of skill-based conditioning games. Journal of Strength and Conditioning Research, 16, 236-241.

Garn, S.M., Leonard, W.R., \& Hawthorne, V.M. (1986). Three limitations of the body mass index. American Journal of Clinical Nutrition, 44(6), 996-997.

Grgantov, Z. (2003). Kondicijska priprema u odbojci (Conditioning in volleyball). In D. Milanović \& I. Jukić (Eds.), Proceedings, International Scientific and Professional Conference "Fitness Preparation of Athletes", (pp. 460-465). February 21-22, Zagreb: Faculty of Kinesiology, University of Zagreb. In Croatian

Hammami, A., Randers, M. B., Kasmi, S., Razgallah, M., Tabka, Z., Chamari, K., et al. (2018). Effects of soccer training on health-related physical fitness measures in male adolescents. Journal of Sport and Health Science, 7(2), 169-175.

Han J.C., Lawlor D.A., \& Kimm S.Y. (2010). Childhood obesity. Lancet, 375, 1737-1748. 
Hardman, K. (2007). Current situation and prospects for physical education in the European Union - study. Brussels: The European Parliament's committee on Culture and Education.

Harvey, S., \& Jarrett, K. (2014) A review of the game-centered approaches to teaching and coaching literature since 2006. Physical Education and Sport Pedagogy, 19(3), 278-300.

Hills, A.P., Andersen, L.B., \& Byrne, N.M. (2011). Physical activity and obesity in children. British Journal of Sports Medicine, 45(11), 866-870.

Jurg, E.M., Kremers, P.J.S., Candel, J.J.M.M., van der Wall, F.M., \& de Meij, S.B.J. (2006). A controlled trial of a school-based enviromental Intervention to improve physical activity in Dutch children: JUMP-in, kids in motion. Health Promotion International, 21(4), 320-330.

Keppel, G. (1991). Design and analysis: A researcher's handbook (3rd ed.). Upper Saddle River,NJ: Prentice Hall.

Kirk, D. (2006). The 'obesity crisis' and school physical education. Sport, Education and Society, 11(2), 121-133.

Koutedakis, Y., \& Bouziotas, C. (2003). National physical education curriculum: motor and cardiovascular health related fitness in Greek adolescents. British Journal of Sports Medicine, 37, 311-314.

Lazaar, N., Aucouturier, J., Ratel, S., Rance, M., Meyer, M., \& Duché, P. (2007). Effect of physical activity intervention on body composition in young children: influence of body mass index status and gender. Acta Paediatrica, 96(9), 1321-1325.

Ljubojević, M., Višnjić, D., \& Ilić, J. (2012). Praćenje efekata programa košarke kao izabrane sportske aktivnosti u nastavi fizičkog vaspitanja na antropomorfološki status učenika (Monitoring the effects of the basketball program as a elective sport activity in physical education curriculum on the anthropomorphological status of students). Inovacije u nastavi - časopis za savremenu nastavu, 25(3), 4855. In Serbian

Malina, R.M. (2004). Secular trends in growth, maturation and physical performance: a review. The Annual Review of Anthropology, 67, 3-31.

Marelić, N., Janković, V., Rešetar, T., \& Marelić, S. (2000.) Učenje odbojke putem modificiranih igara (Teaching volleyball through modified games). In M. Andrijašević (Ed.), Proceedings of the International Conference "Leisure and Play" (pp. 130-133). Zagreb: Faculty of Kinesiology, University of Zagreb. In Croatian

Milanović, Z., Pantelić, S., Kostić, R., Trajković, N., \& Sporiš, G. (2015). Soccer vs. running training effects in young adult men: which programme is more effective in improvement of body composition? Randomized controlled trial. Biology of Sport, 32(4), 301-305.

Milenković, V. (2002). Efekti primene eksperimentalnog programa sa akcentom na sportsku gimnastiku na neke motoričke sposobnosti učenika sedmog razreda osnovne škole (Effects of applying an experimental program with an emphasis on gymnastics on some motor skills of seventh grade students). In R. Popović (Ed.) Proceedings of the Scientific Congres "FIS Communications in Physical Education, Sport and Recreation ", (pp. 291-300), Niš: Faculty of Physical Culture, University of Niš. In Serbian

Mirwald, R.L., Baxter-Jones, A.D., Bailey, D.A., \& Beunen, G.P. (2002). An assessment of maturity from anthropometric measurements. Medicine and Science in Sports and Exercise, 34(4), 689-694.

Nathan, B.M., \& Moran, A. (2008). Metabolic complications of obesity in childhood and adolescence: More than just diabetes. Current Opinion in Endocrinology, Diabetes and Obesity, 15, 21-29.

Norton, K., Marfell-Jones, M., Whittingham, N., Kerr, D., Carter, L., Saddington, K., \& Gore, C.J. (2000). Anthropometric assesment protocols. In C.J. Gore, (Ed.), Physiological tests for elite athletes, (pp. 66-85). Champaign, IL: Human kinetics.

Owen, A., Twist, C., \& Ford, P. (2004). Small-sided Games: The physiological and technical effect of altering pitch size and player numbers. Insight - The Football Association Coaches Association Magazine, 7(2), 50-53.

Pate, R.R., Davis, G.M., Robinson, N.T., Stone, J.E., Mckenzie, L.T., \& Young, S.J. (2006). Promoting physical activity in children and youth. Circulation, 114(11), 1214-1224.

Pate, R.R., Heath, G.W., Dowda, M., \& Trost, S.G. (1996). Associations between physical activity and other health behaviors in a representative sample of US adolescents. American Journal of Public Health, 86(11), 1577-1581.

Pereira, P.F., Serrano, H.M.S., Carvalho, G.Q., Ribeiro, S.M.R., Peluzio, M.D.C.G., Franceschini, S.D.C.C., et al. (2015). Measurements of body fat distribution: Assessment of collinearity with body mass, adiposity and height in female adolescents. Revista Paulista de Pediatria, 33(1), 63-71.

Phillips, S.M., Bandini, L.G, Compton, D.V., Naumova, E.N., \& Must, A. (2003). A longitudinal comparison of body composition by total body water and bioelectrical impedance in adolescent girls. The Journal of Nutrition, 133(5), 1419-1425.

Pinel, J.P. (2010). Biopsychology ( $8_{\text {th }}$ Ed.) New Yersey: Prentice Hall. 
Rech, C.R., Cordeiro, B.A., Petroski, E.L., \& Vasconcelos, F.A. (2008). Validation of bioelectrical impedance for the prediction of fat-free mass in Brazilian elderly subjects. Arquivos Brasileiros de Endocrinologia \& Metabologia, 52, 1163-1171.

Regaieg, S., Charfi, N., Kamoun, M., Ghroubi, S., Rebai, H., Elleuch, H., et al. (2013). The effects of an exercise training program on body composition and aerobic capacity parameters in Tunisian obese children. Indian Journal of Endocrinology and Metabolism, 17(6), 1040-1045.

Rešetar, T., Đurković, T., Marelić, S., \& Borovina, H. (2008). Razlike u strukturi igre odbojke 6: 6 i 3: 3 (Differences in volleyball game structure 6:6 and 3:3). In B. Neljak (Ed.), Proceedings of the Conference "State and perspective of development in the fields of education, sport, sports recreation and kinesitherapy ", (pp. 550-555). Zagreb: Croatian Kinesiology Association. In Croatian

Rey-López, J.P., Vicente-Rodríguez, G., Biosca, M., \& Moreno, L.A. (2008). Sedentary behaviour and obesity development in children and adolescents. Nutrition, Metabolism and Cardiovascular Diseases, 18(3), $242-251$.

Sallis, F.J., Mckenzie, L.T., Alcaraz, E.J., Kolody, V., Faucette, N., \& Hovell, F.M. (1997). The effects of $2-$ year physical education program (SPARK) on physical activity and fitness in elementary school students: Sports, play and active recreation for kids. The American Journal of Public Health, 87(8), 1328-1334.

Schwandt, P., von Eckardstein, A., \& Haas, G.M. (2012). Percentiles of percentage body fat in German children and adolescents: an international comparison. International Journal of Preventive Medicine, 3(12), 846-852.

Siervogel, R.M., Demerath, E.W., Schubert, C., Remsberg, K.E., Chumlea, W.C., Sun, S., et al. (2003). Puberty and body composition. Hormone Research in Paediatrics, 60(Suppl. 1), 36-45.

Official Gazette of the Republic of Serbia (2006). Pravilnik o nastavnom planu za drugi ciklus osnovnog obrazovanja $i$ vaspitanja i nastavni program za peti razred osnovne škole (Rulebook on the syllabus for the second cycle of primary education and the curriculum for the fifth grade of primary school). Ministry of Education of the Republic of Serbia, № 6/07, 3/11, 1/13, 4/13, Belgrade. In Serbian

Snijder, M.B., Van Dam, R.M., Visser, M., \& Seidell, J.C. (2005). What aspects of body fat are particularly hazardous and how do we measure them?. International Journal of Epidemiology, 35(1), 83-92.

Stamatović, M., \& Šekeljić, G. (2006). Uticaj različitih koncepcija nastave fizičkog vaspitanja na motorički status učenika mlađeg školskog uzrasta (The influence of different conceptions of physical education curriculum on the motor status of young students). In G. Bala (Ed.) Proceedings of the Interdisciplinary Scientific Conference with International Participation Anthropological Status and Physical Activity of Children and Youth (pp. 301-310), Novi Sad: Faculty of Sport and Physical Education, University of Novi Sad. In Serbian

Stojanović, D., \& Branković, N. (2018). Association between body composition and cardiorespiratory fitness of adolescents. Facta Universitatis Series Physical Education and Sport, 16(2), 297-308.

Stojanović, D., Momčilović, Z., Stojanović, T., \& Stojanović, T. (2019). The effects of skill-based exercises and small-sided games on the motor skills of elementary school students. Glasnik Antropološkog društva Srbije, 54(1-2), In press.

Stojanović, T. (1998). Uticaj nastavnih sadržaja iz košarke na psihosomatski status učenika u nastavi fizičkog vaspitanja (The influence of basketball content on the psychosomatic status of students in physical education curriculum). Unpublished magister thesis. Skopje: Faculty of Physical Education of the SS. Cyril and Methodius University.

Stojanović, T., Bešić, Đ., Stojanović, D., Lilić, Lj., \& Zadražnik, M. (2018). The effects of short-term preseason combined training on body composition in elite female volleyball players. Anthropological Notebooks, 24(1), 85-95.

Trajković, N. (2015). Uticaj situaciono kondicionog treninga na eksplozivnu snagu i preciznost kod odbojkaša (Effects of game based conditioning training on explosive strength and accuracy in volleyball players). Unpublished doctoral dissertation. Niš: Faculty of Sport and Physical Education, University of Niš. In Serbian

Trost, S.G. (2006). Public health and physical education. In D. Kirk, D. MacDonald, \& M. O’Sullivan (Eds.), The handbook of physical education (pp. 163-187). London: Sage.

Viru, A., Loko, J., Harro, M., Volver, A., Laaneots, L., \& Viru, M. (1999). Critical periods in the development of performance capacity during childhood and adolescence. European Journal of Physical Education, 4(1), 75-119.

Weiner J., \& Lourie J. (1969). Human Biology, a Guide to Field Methods, International Biological Programe. Oxford-Edinburgh: Blackwell Scientific Publications.

World Health Organization-WHO. (2016). Fiscal policies for diet and prevention of noncommunicable diseases: Technical meeting report (5-6 May 2015, Geneva, Switzerland). Geneva: WHO Document Production Services. 
World Medical Association Declaration of Helsinki (2013). Ethical principles for medical research. Jama, 310(20), 2191-2194.

Zegnal-Koretić, M. (2017). Uticaj obima i sadržaja kretnih aktivnosti na radnu sposobnost $i$ telesni sastav mlađih adolescenata koprivničko-križevačke županije (The impact of exercise, its range and quality on work capacities and body mass index of young adolescents from Koprivnica-Križevci county). Unpublished doctoral dissertaiton. Sremska Kamenica: Faculty of Sport and Tourism, Educons University. In Serbian

\section{EFEKTI PROGRAMA SITUACIONIH VEŽBI I IGARA NA SKRAĆENOM PROSTORU NA TELESNU KOMPOZICIJU UČENIKA}

Sa ciljem da se utvrde efekti programa situacionih vežbi i igara na skraćenom prostoru na telesnu kompoziciju učenika, sprovedeno je istraživanje na 90 ispitanika, prosečne starosti 13 godina koji su podeljeni po polu, a zatim slučajnim izborom svrstani u dva subuzorka: eksperimentalni [SS1; N=39 (CG1, 19 devojčica i CG2, 20 dečaka)] i kontrolni subuzorak [SS2; $N=51$ (CG1, 24 devojčica $i$ CG2, 27 dečaka)]. Parametri telesne kompozicije su procenjeni kaliperom (debljina kožnih nabora) i metodom bioelektrične impedance, tj., uređajem Omron BF511 (procenat masnog i mišićnog tkiva). Nakon primene 16-to nedeljnog programa situacionih vežbi i igara na skraćenom prostoru iz odbojke, svi parametri telesne kompozicije značajno su se poboljšali kod EG (osim procenta masnog tkiva kod devojčica, i mase masnog tkiva kod oba pola). U eksperimentalnom periodu ispitanici SS2 su zabeležili značajne promene u telesnoj kompoziciji u vidu povećanja masnog tkiva (kod oba pola), smanjenja mišićnog tkiva kod dečaka i povećanje kod devojčica. Rezultati ovog istraživanja pokazali su da je bilo značajnih razlika između efekata dvaju programa na telesnu kompoziciju na multivarijantnom nivou, zatim je na univarijantnom nivou uočeno da ispitanici SS1 nakon primene eksperimentalnog programa imaju znatno bolje rezultate u odnosu na ispitanike SS2 u parametrima telesne kompozicije u vidu smanjenja kožnih nabora, masnog tkiva i povećanja mišićnog tkiva kod oba pola. Dobijeni rezultati ukazuju da je ovakav eksperimentalni program pogodan za intenzifikaciju nastave fizičkog vaspitanja $i$ pozitivne promene u telesnoj kompoziciji učenika osnovnih škola.

Ključne reči: telesna kompozicija, situacione vežbe, igre na skraćenom prostoru, fizičko vaspitanje, učenici. 